\title{
Framework and Development of Malaysian Business Ethics Module
}

\author{
Khalidah Khalid Ali ${ }^{1}$ * Mohd Nizam Mohd Ali ${ }^{2}$, and Siti Aisyah Panatik Abdul Rahman ${ }^{3}$
}

\begin{abstract}
Malaysia is striving to be a developed nation by the year 2020 as well as realize the aspirations of Dasar Transformasi Nasional within an open economy supporting globalization. The government, through its socio-economic and development policies has been promoting entrepreneurship and small businesses to sustain the nation's economic growth in a challenging competitive global ecosystem. Small and medium enterprises (SMEs) play a vital role in the Malaysian economy and are considered to be the backbone of the nation's industrial development. Latest statistics show that $99.6 \%$ of local businesses are micro, small and medium enterprises. As much as they play an important role in driving the nation's economic growth, a quantitative research study by the Malaysian Ministry of Domestic Trade, Cooperatives and Consumerism, Integriti Malaysia and Universiti Teknologi Malaysia in 2014 has significantly found that ethics has not been comprehensively applied in the conduct of small and micro-businesses in Malaysia. In addition, these businesses lack exposure to ethics training and education. As business ethics is important to sustain customers' loyalty, avoid legal suits as well as drive foreign direct investment for the nation's economic and societal wellbeing, there is a critical need to educate small and micro-businesses on ethics. Consequently, a collaborative government-academic national level research project was initiated in mid-2017 to develop a Malaysian business ethics module, Etika Perniagaan Malaysia (EPM) to address this gap. This paper shares the framework, method and content development of the business ethics module to establish and train the Professional Practitioners Group (PPG) from public and private institutions as well as related non-governmental institutions to impart business ethics knowledge to small and microbusinesses in Malaysia through active learning methods. The module hence aspires to create consciousness on the importance of ethics and its application in business for economic and social sustainability.
\end{abstract}

Keywords: Business Ethics, Module, Small and Medium Enterprises (SMEs), Micro-business, Professional Practitioners Group

\section{Introduction and Background}

\footnotetext{
$1 *$ Corresponding author: Khalidah Khalid Ali is Senior Lecturer at Department of Management and Humanities, Universiti Teknologi Petronas, Seri Iskandar, 32610, Perak Darul Ridzuan, Malaysia. Email address: khalidah_kh@utp.edu.my

${ }^{2}$ Dr. Mohd Nizam Mohd Ali is Senior Director, The Malaysian Integrity Institute (Integriti Malaysia), Persiaran Tuanku Syed Sirajuddin, Bukit Tunku, 50480 Kuala Lumpur, Wilayah Persekutuan Kuala Lumpur Malaysia. Email: nizam@integriti.my

${ }^{3}$ Associate Professor Dr. Siti Aisyah Panatik Abdul Rahman is Deputy Dean (Academic and Student Development), Faculty of Management, Universiti Teknologi Malaysia, 81310 Johor Bahru, Johor, Malaysia. Email: saisyah@utm.my
} 
The full research is a policy study involving academics and government agencies with Ministry of Domestic Trade, Cooperatives and Consumerism, Malaysia as the grant provider. The research aims at realizing Sasaran 3 Pelan Integriti Nasional (PIN)), in line with Teras Strategi 2 Pelan Hala Tuju KPDNKK 2015-2020. (Note: This study supports the "entrepreneurship" objectives of the Tenth ( 2010-2015) and Eleventh Malaysia Plans (2016-2020) to realize Vision 2020. Please also refer to Eleventh Malaysia Plan (2016-2020). Accessed from http://www.epu.gov.my/en/rmk/eleventh-malaysia-plan-2016-2020 on 9 February 2018).

There are three identified inter-related project phases aimed at embedding ethics and integrity among micro, small and medium businesses in Malaysia from the period, 2014 till 2020. However, this paper will only cover Phase 3 of the full project, i.e. Perlaksanaan Program Merakyatkan Etika Perniagaan Malaysia (2017-2020). Please refer to "Terma Rujukan Perunding Industri: Projek Merekayasa Pertumbuhan Ekonomi Untuk Peningkatan Kemakmuran and the diagram on page 4 i.e. Perlaksanaan Program Merakyatkan Etika Perniagaan Malaysia (2017-2020) as well as Attachment 1 of this paper. It aims to share the development of a business ethics module, Modul Etika Perniagaan Malaysia (EPM) by a team of research consultants from Universiti Teknologi Malaysia (UTM), Ministry of Domestic Trade, Cooperatives and Consumerism, Malaysia, KPDNKK), Integriti Malaysia (IIM) and Universiti Teknologi PETRONAS (UTP) in 2017.

This paper presents the conceptual framework for promoting the development of business ethics module in Malaysia. It also provides an overview of the method and content development of the business ethics module to establish and train Professional Practitioners Group (PPG) from public and private institutions as well as related non-governmental organizations (NGOs) to impart business ethics knowledge to small and micro-businesses in Malaysia through active learning methods. The module hence aspires to create consciousness on the importance of ethics and its application in business for economic and social sustainability.

This paper may also be classified as an industry paper to share a collaborative effort between the public sector, the private sector and academic institutions to develop a Malaysian business ethics module for the PPG to educate and embed ethics among small and micro-businesses in Malaysia.

\subsection{SMEs and their Contributions to the Malaysian Economy}

Malaysia aspires to be a developed nation by the year 2020 as well as realize Dasar Transformasi Nasional within an open economy supporting globalization. The government, through its socio-economic and development policies has been promoting entrepreneurship and small businesses to sustain the nation's economic growth in an ever challenging competitive global environment.

SMEs have been significantly contributing to the Malaysian economy since 1970s when Malaysia transformed from an agricultural to a manufacturing and industrial nation. 99.2 percent of the overall business establishments in Malaysia are SMEs (Nurulhasanah, Zulnaidi and Rafisah, 2016). Current 2018 figures show that SMEs contribute to 99.6 per cent of local businesses in Malaysia (Hafsah, 2018). In addition, micro-businesses dominate the SME with 77 percent, while 20 percent of the business establishments are small businesses and 3 percent are the medium enterprises (Hashim, 2015).

Figure 1 illustrates the definition of SMEs in Malaysia with effect from 1 April, 2014.

\begin{tabular}{|c|c|}
\hline Manufacturing & Services and Other Sectors \\
\hline $\begin{array}{c}\text { Sales turnover: } \\
\text { RM15 mil } \leq \text { RM50 mil } \\
\underline{\text { OR }} \\
\text { Employees: From } 75 \text { to } \leq 200\end{array}$ & $\begin{array}{c}\text { Sales turnover: } \\
\text { RM3 mil } \leq \text { RM20 mil } \\
\\
\text { OR } \\
\text { Employees: }\end{array}$ \\
\hline $\begin{array}{c}\text { Sales turnover: } \\
\text { RM300,000 < RM15 mil } \\
\text { OR } \\
\text { Employees: From } 5 \text { to }<75\end{array}$ & $\begin{array}{l}\text { Sales turnover: } \\
\text { RM300,000 < RM3 mil } \\
\text { Employees: } \frac{\text { OR }}{\text { From } 5 \text { to }<30}\end{array}$ \\
\hline $\begin{array}{l}\text { Sales turnover: } \\
<\text { RM300,000 } \\
\text { OR } \\
\text { Employees: < } 5\end{array}$ & $\begin{array}{c}\text { Sales turnover : } \\
<\text { RM300,000 } \\
\text { OR } \\
\text { Employees: }<5\end{array}$ \\
\hline
\end{tabular}


Aptly, SMEs play a vital role in the Malaysian economy and are considered to be the backbone of the country's industrial development (Ali Salman, and Nelson Oly Ndubisi, 2006; Mohd Zulkifli, Abdul Kamal, Mohd Rushdan and Zakiah, 2010). To highlight some of their significant achievements, SMEs have contributed up to $33.1 \%$ of the nation's Gross Domestic Product (GDP) and the government has targeted that SMEs will assist the country in contributing up to 41\% GDP by the year 2020 (Siti Fatimah, Rosita and Amer Shakir, 2015; Hafsah, 2017). In addition, SMEs employ 56 percent of Malaysia's total workforce (SMEinfo, 2011) and the value added products are expected to worth RM120 billion in the manufacturing sector in 2020 (Abul Bashar, Jamaliah, Md. Daud, Mohd Fauzi, and David Yong, 2016). These statistics hence reveal the pertinent role of SMEs, especially small and micro-businesses in driving growth, stability and sustainability of the Malaysian economy.

However, business ethics practices in Malaysia have come under scrutiny in recent years due to its commendable economic growth of more than 8 per cent per year from 1987-97; partly an outcome of the nation's "rapid growth" economic goal. Consequently, these developments have resulted in lack of ethics among businesses to reap quick gains in the quest for profit maximization. Realizing this, there is a serious need to enhance corporate governance, business ethics and corporate social responsibility of Malaysian businesses.

Significant intiatives have no doubt been undertaken by big corporations to embed ethics through compliancebased and integrity-based code of ethics, not to mention corporate social responsibility projects. However, based on a quantitative research study by Universiti Teknologi Malaysia (UTM), Ministry of Domestic Trade, Cooperatives and Consumerism (KPDNKK) and Malaysian Integrity Institute (Integriti Malaysia) in 2014, there seem to be lack of ethics knowledge and practice among small and micro-businesses, especially retailers and hawkers community that represent a major cohort of micro-businesses in Malaysia. In fact, the said study, through the Corporate Integrity Assessment Questionaires (CIAQ) has validly found that ethics has not been comprehensively applied in the conduct of small and micro-businesses in Malaysia (0-25\%). In addition, these businesses lack exposure to ethics training and education (0-25\%).

As ethics in business is important, among others, to sustain customers' loyalty, avoid legal suits as well as drive foreign direct investment for the nation's economic and societal wellbeing, there is a critical need to educate Malaysian small and micro-businesses on ethics. Considering this, a continued collaborative industry-academic project between the Malaysian Ministry of Domestic Trade, Cooperatives and Consumerism (KPDNKK), the Malaysian Integrity Institute (Integriti Malaysia), Universiti Teknologi Malaysia (UTM) and Universiti Teknologi PETRONAS (UTP) was initiated in mid-2017 to develop a Malaysian business ethics module as part of a threephase strategic implementation roadmap for business ethics outreach programme from 2017 to 2020.

\section{Literature Review}

\subsection{Ethics and its Importance in Business Organizations}

Ethics is the study of morality (Nickels, et al.,2008) and a branch of philosophy (Landauer and Rowlands, 2001). According to Stanwick and Stanwick (2009), it relates to the values an individual use to interpret whether any particular action or behaviour is considered acceptable and appropriate. Hence, ethics investigates questions of right and wrong, duty and obligations, moral responsibility (Shaw, 2011) and justice (Boatright, 2012) through application of relativistic and objectivistic ethical principles (Shaw, 2011; Boatright, 2012; Desjardins, 2009) including religion (Khalidah et al., 2014). The application of ethics is ultimately important in all aspects of an individual's life; be it business or non-business (Khalidah et al., 2015), what more in the development of a civil society promoting ethics for general wellbeing.

Placing in context with this study, the fundamental purpose of every business is to make profit by providing products and services that satisfy human needs (Steiner and Steiner, 2012), while taking calculated risks (Khalidah et al., 2015). Hence, one distinguishing feature of a business is its economic character (Boatright, 2012; Khalidah et al., 2018). A typical business takes place in organizations, designed to achieve a set of goals within the defined roles played by members of the organization. In organizational setups, there is also a need to balance and fulfill the interests of stakeholders (especially primary stakeholders such as investors, employees, customers, suppliers and the surrounding community). The bigger the business, the more the number of stakeholders it has to please. 
Business ethics is a process of rationally evaluating moral standards and applying them to business institutions Velasquez, 2012; Crane and Matten, 2010, Nickels et al.,2008). It is therefore the study of business situations, activities and decisions where issues of right and wrong are addressed (Crane and Matten, 2010) including social justice (Khalidah et al., 2018). The importance of applying ethics in the world of business is listed below;

- To keep existing customers: maintain customer loyalty and business sustainability.

- To attract new customers: Good business or corporate image will attract new customers and increase profitability.

- To avoid lawsuits: Comply with laws and regulations to maintain good image and dignity.

- To reduce employee turnover: Maintain employee loyalty. This will subsequently increase organizational effectiveness.

- To please customers, employees and society: Strive to fulfil the needs and interests of main stakeholders i.e. customers, employees and the community they serve.

Much as business ethics and its importance have been highlighted, capitalistic/free market ideologies more often advocate a view that ethics and business are contradicting concepts. In fact, some capitalist advocates opine that ethics is an oxymoron in business as resources are meant to be exploited for the production of goods and services to reap economic gains (Khalidah et al., 2015; Khalidah et al., 2017d). Nevertheless, several issues emerge as food for thoughts in the conduct of business;

(a) Are doing business and being ethical so contradictory that it is impossible to be both an effective business manager and an ethical individual? The perception that business and ethics are contradictory concepts is based on a generally accepted view of what managers are supposed to do and, thus, how they are supposed to act.

(b) Some people object to the view that ethical standards should be applied to the behaviour of people in business organizations on the basis that business persons should single-mindedly pursue the financial interests of their firm and not side track their energies or their firm's resources into doing "good works." This view is supported by three arguments;

i) In perfectly competitive/free markets, the pursuit of profit by itself ensures that society members are served in the most socially beneficial ways. To be profitable, each firm has to produce only what members of society want and has to do this by the most efficient means available. However, most markets are not "perfectly competitive." Firms do not have to compete; they can even maximize profits despite inefficient production. On the issue of increasing profits which will lead to social benefits, often they also lead to injuries/ social costs to the society. E.g. uncontrolled pollution, deceptive advertising, concealing product hazards, fraud, bribery, tax evasion, price fixing and so on (Steiner and Steiner, 2012).

ii) Business managers should single mindedly pursue the interests of their firms and ignore ethical considerations as Alex C. Michales called the "loyal agent's argument (Velasquez, 2012). There should be undivided loyalty as an agent of the employer. A manager has therefore a duty to serve the employer in every way that will advance the employers' interests.

iii) The objection to be ethical also comes from the argument that to be ethical is enough for business people to follow the law: if it is legal, then it is ethical. It is wrong to see ethics as no more than the law requires (Velasquez, 2012; Ebert and Griffin, 2007). Of course, most ethicists agree that all citizens have a moral obligation to obey the law as long as the law does not require clearly unjust behaviour. In other words, it is immoral to break the law. However, ethics is above the law (Shaw, 2011; Boatright, 2012; Ebert and Griffin, 2007). It requires selfconscience, commitment and conviction to moral actions as a social responsibility (Khalidah et al., 2014; Khalidah et al., 2018).

Although the above justifications and relativistic reasoning are duly noted and respected, the lessons learned from the collapse of Enron, Arthur Anderson, World.com and the consequences of socially irresponsible act of San Lu Corporation to supply tainted milk are simply too serious to ignore (Desjardins, 2009; Boatright, 2012; Khalidah et al., 2018). Likewise, recent Malaysian conflict of interest cases involving private and public institutions such as Port Kelang Free Trade Zone, I MDB and FELDA Global Venture cases have been highlights in mainstream media, tarnishing the image of Malaysia as a highly middle - income economy that is striving to achieve a developed status. 
Indeed, it is important for business people to be ethical as being ethical in business is no different than being ethical in private life. Business organizations comprise of humans who have the body, mind and heart (soul) to make rational and logically sound decisions. Good and effective business decisions will seriously consider the integration of economic, legal and moral viewpoints for social justice (Boatright, 2012; Khalidah et al., 2014). After all, businesses are components of a civil society promoting ethics for general wellbeing. In sum, today, businesses have many reasons to be consciously concerned with ethical standards of their organizations as a social responsibility; to maximize the positive impacts and minimize the negative impacts on society members.

\subsection{Active Learning as a Training Methodology}

Active learning describes the instructional strategies and includes a wide range of activities that share the common element of "involving learners (i.e. students, course participants, etc) in doing things and thinking about the things they are doing" (Bonwell and Eison, 1991). Examples are presentations,discussions, questioning purposefully (reflections), employing classroom demonstrations, assigning short "in- class writing", using popular films and videos and inviting guest speakers. Active learning also connects course content to current events, creating assignments, integrating debates, using case method teaching, field trips and summative assessment strategies such as tests or quizzes (Bonwell and Eison, 1991; Eison, 2010; Azizul Azri , 2016).

As active learning incorporates a variety of methods to explore, it may be an appropriate methodology to adopt in an attempt to integrate the phenomenal concept of ethics and spirituality in modular development of courses within competitive environments (Khalidah, 2017a).This is in line with the Malaysian Higher Education Blueprint - 2015-2025 (Khairiah, Syed Ahmad Helmi, Aziatul Niza and Azizul Azri, 2016).

The Malaysian Business Ethics Module (EPM) applies active learning as a method in its development for the Professional Practitioner Group (PPG) to impart business ethics knowledge to small and micro-business operators.

\subsection{The Malaysian Business Ethics Module (EPM) Development as the Third Phase of Full Project - 2017-2020}

At the beginning of this paper, it is noted that there are three identified inter-related project phases from 2014 till 2020. The first phase involves a quantitative study in 2014 to identify the level of understanding and ethical practices, problems and support needed by SMEs through a questionnaire (refer attachment on CIAQ findings). The findings have been used to develop the short and long term strategic plans for human resource development of Malaysian micro, small and medium size business operators and entrepreneurs.

The second phase continues in 2015 with the preparation of the Malaysian Code of Business Ethics, outlining 10 principles and incorporation of legislative acts under the supervision of various government institutions and agencies such as Malaysian Ministry of Domestic Trade, Cooperatives and Consumerism (KPDNKK), Companies Commission of Malaysia (CCM/SSM), etc. The 10 business ethics principles are (i) competition (ii) prohibition on giving and receiving kickback bribery (iii) asset management (iv) resource management (v) advertising and promotion (vi) protection of intellectual property (vii) declaration of interests (viii) environment (ix) safety and health of traders and employees (x) reporting of misconduct and non-compliance with the conduct of business ethics. The Malaysian Business Code of Ethics has been formalised as a government policy and published in 2015 for distribution in all the languages of Malaysia's main ethnic groups ( i.e. Malay, Chinese and Indian). Translations are also available in English as well as Sabah and Sarawak dialects i.e Kadazan and Iban respectively. A sample cover page of the Malaysian Business Code of Ethics is included as an attachment of this paper. Please refer also to the background (latarbelakang) section of Terma Rujukan Perunding Industri Projek Merekayasa Pertumbuhan Ekonomi untuk Peningkatan Kemakmuran on other publicity and promotional drives to realize this national initiative. Figure 2 diagramatically summarizes the 10 business ethics principles for Malaysia (translated in English). 


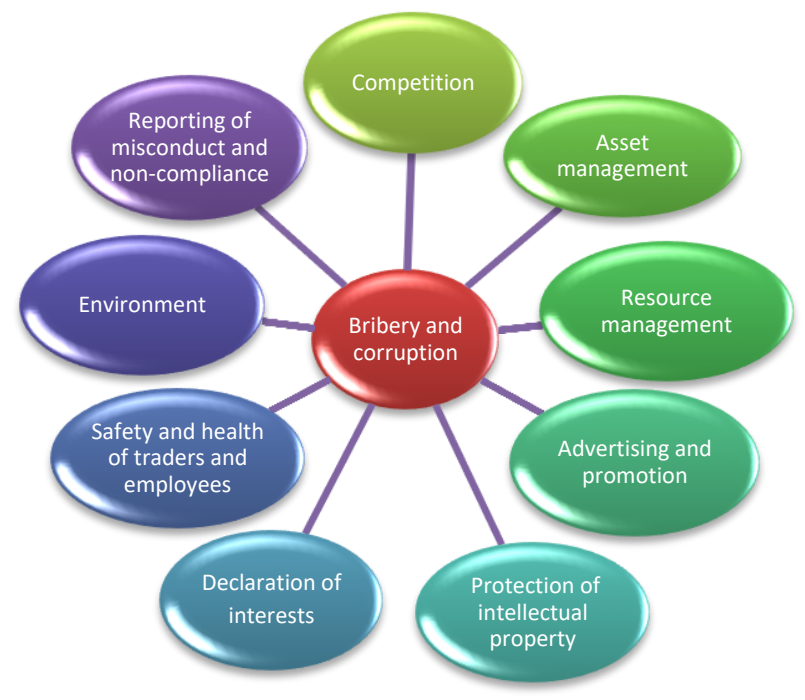

Figure 2 : The Ten (10) Business Ethics Principles for Malaysia

Consequently, the third phase, from 2017-2020 involves the development of the Malaysian Business Ethics Module or Etika Perniagaan Malaysia (EPM) based on the 10 business ethics principles (as above) and the CIAQ findings to justify for the module framework and development. As earlier mentioned, the main objective behind the module development is for the Professional Practitioners Group (PPG) to teach as well as drive business ethics awareness to micro, small and medium businesses in Malaysia through active learning methods.

\subsection{The Malaysian Business Ethics Module: Framework and Development}

This sub-section elaborates on the framework, development and content of the EPM module including its justifications and strategic implementation as a roadmap for business ethics outreach programme from 2017 to 2020. Refer to page 4 of Terma Rujukan Perunding Industri Projek Merekayasa Pertumbuhan Ekonomi untuk Peningkatan Kemakmuran i.e. Program Merakyatkan Etika Perniagaan Malaysia - 2017-2020.

Further illustrations are provided in Figures 3, 4 and 5 below.

\begin{tabular}{|c|c|c|}
\hline No. & $\begin{array}{c}\text { CIAQ } \\
\text { DIMENSIONS }\end{array}$ & $\begin{array}{l}\text { PERCENTAGE } \\
\text { LEVEL }\end{array}$ \\
\hline 1 & Goals & $0 \%-25 \%$ \\
\hline 2 & Leadership & $0 \%-50 \%$ \\
\hline 3 & Infrastructure & $0 \%-50 \%$ \\
\hline 4 & $\begin{array}{l}\text { Compliance and } \\
\text { Order }\end{array}$ & $0 \%-50 \%$ \\
\hline 5 & Business Culture & 0\% \\
\hline 6 & Disciplinary Actions & $0 \%-25 \%$ \\
\hline 7 & Advice and Support & $0 \%-25 \%$ \\
\hline 8 & $\begin{array}{c}\text { Ethics Training and } \\
\text { Education }\end{array}$ & $0 \%-25 \%$ \\
\hline
\end{tabular}




\begin{tabular}{|c|c|c|}
\hline $\mathbf{9}$ & $\begin{array}{c}\text { Communication } \\
\text { Ethics }\end{array}$ & $0 \%-50 \%$ \\
\hline $\mathbf{1 0 .}$ & $\begin{array}{c}\text { Information } \\
\text { Sharing }\end{array}$ & $\mathbf{0 \%}-\mathbf{2 5 \%}$ \\
\hline
\end{tabular}

Figure 3: Why is the Malaysian Business Ethics Module (EPM) Important? CIAQ Study

Figure 3 addresses the justification for the EPM module development based on the findings from CIAQ research study in 2014. As seen, dimension No. 8 has revealed that respondents' level of ethics training and education is low i.e. between 0-25\%. In addition, other dimensions that have registered 0-25\% level (No. 1, 6, 7, and 10) have been given due focus in the development of the module to address gaps. For example, the dimension of business culture (budaya perniagaan) and information sharing (pemberitahuan maklumat).

Figure 4 illustrates the implementation strategy for the EPM module with the establishment and involvement of the PPG in imparting business ethics knowledge to the micro, small and medium businesses. At the initial phase, the target groups to address are the retailers and hawker community in Malaysia.

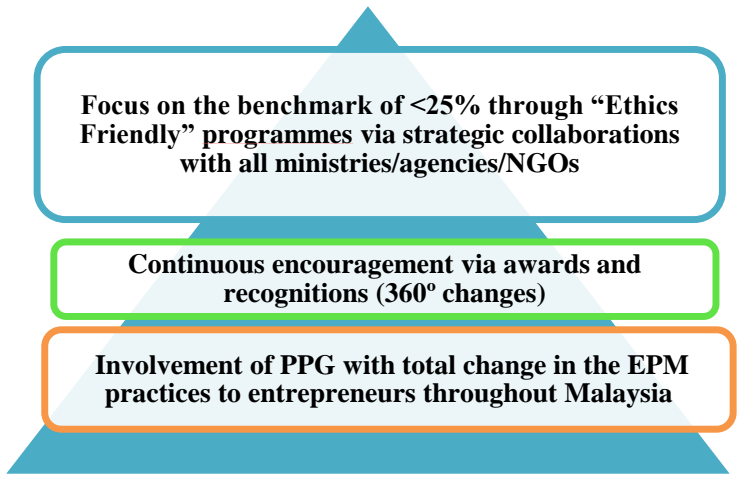

Source: Translated from Kajian Corporate Integrity Assessment Questionnaires (CIAQ) 2014 oleh penyelidik Universiti Teknologi Malaysia (UTM) dengen kerjasama KPDNKK dan Institut Integriti Malaysia (INTEGRITI)

\section{Figure 4: Implementation Strategy for the Malaysian Business Ethics Module (EPM)}

The EPM module comprises of 4 sub-modules, developed with specific objectives; i.e. Module 1, to create participants' awareness and consciousness; Module 2, to develop application skills; Module 3, to sharpen analytical ability and Module 4 for synthesis of knowledge. For the actual module development, the researchers have applied several active learning methods and a variety of experiential learning mediums to equip the PPGs with skills and knowledge on business ethics. They include lecture materials, short cases and situations, role play scenarios, business games and videos for reflection. 23 situations, 17 cases, 7 role play scenarios and 9 videos with synopsis including guidelines on each method have been presented in the module itself. Blooms Taxonomy is also referred and applied to craft the four (4) sub-modules as seen in Figure 5 below. 


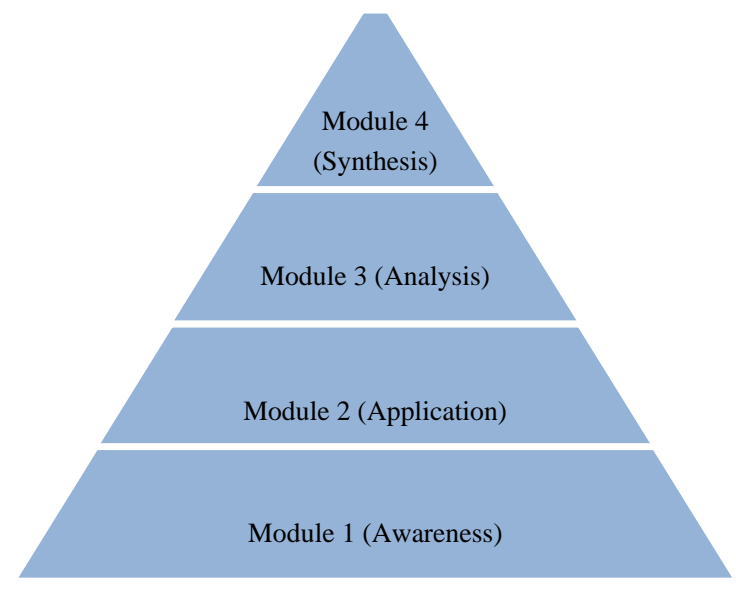

Figure 5: The Framework for EPM Business Ethics Module for Malaysia

Prior to the actual module development, a kick-off workshop was organized in mid-August, 2017 with the PPGs. They have been guided to create real life business ethics situations and cases based on their experience while executing job tasks and responsibilities. These were incorporated in the module in addition to other developed cases and situations by the research consultants themselves. These cases are related to contemporary business issues from Malaysian contexts Consequently, a workshop among the research consultants was organized in mid-October, 2017 to consolidate the inputs for the actual module development.

\subsection{Piloting the Malaysian Business Ethics Module and Next Steps}

With the developed EPM module, a pilot workshop followed in mid-December, 2017 with active involvement of the 8 research consultants who played the role of master trainers, 2 secretariat personnel and 26 participants i.e. the PPGs. The main workshop objectives are to train the PPGs as well as gather comments and feedbacks for the module improvements (Refer to Laporan Akhir Projek Membangunkan Modul Etika Perniagaan Malaysia, 7 Februari, 2018 as well as Modul Etika Perniagaan Malaysia (Versi Rintis), 16 Disember, 2017).

Representation of the PPGs is encouraging with participation of senior and middle level officials from 18 government institutions/agencies and 2 private corporations as follows:

1. Bahagian Pembangunan Perniagaan, KPDNKK

2. Bahagian Penjaja dan Peniaga Kecil, KPDNKK

3. Bahagian Perdagangan Dalam Negeri, KPDNKK

4. Bahagian Pembangunan Francais, KPDNKK

5. Bahagian Dasar dan Perancangan Strategik, KPDNKK

6. Bahagian Industri Perkhidmatan, KPDNKK

7. Bahagian Penyelidikan dan Dasar Kepenggunaan, KPDNKK

8. Bahagian Pembangunan Koperasi, KPDNKK

9. Bahagian Sumber Manusia, KPDNKK

10. Ministry of Agriculture and Agro-based Industry, Malaysia (MOA)

11. The Cooperatives Commission of Malaysia (Suruhanjaya Koperasi Malaysia (SKM)

12. Malaysia External Trade Development Corporation (MATRADE)

13. Ministry of International Trade and Industry (MITI)

14. SME Corporation Malaysia (SMECorp Malaysia)

15. The Malaysia Competition Commission (MyCC)

16. Maktab Koperasi Malaysia (MKM)

17. Intellectual Property Corporation of Malaysia (MyIPO)

18. Companies Commission of Malaysia (CCM/SSM)

19. TESCO

20. AEON

The workshop has met its objectives i.e. to gather feedbacks on the module as well as expose the PPGs to the contents since the module will be a source of reference for them to train and educate the micro, small and medium 
business operators/entrepreneurs on ethics. Apart from training the PPGs and providing guidelines and knowledge on the techniques of using the module, the research consultants (i.e. the master trainers) have also gathered new ideas, positive comments and commitment from the PPGs/participants. The PPGs have been duly trained on how to be effective trainers to create awareness and conscience on importance of ethics in business through the module contents. Consequently, the developed module has been further finetuned before actual printing and distribution by the Malaysian Ministry of Domestic and Consumer Affairs and Consumerism in 2018.

\section{Conclusion}

Business ethics has been a global concern since the millenium. The Government of Malaysia has made serious efforts to institutionalize ethics and integrity among society members through various initiatives. This paper has presented the conceptual framework for promoting the development of business ethics module in Malaysia. It has also generally shared the method and content development of the Malaysian business ethics module (EPM). Consequently, it has recognized the establishment of the Professional Practitioners Group (PPG) from public and private institutions including related non-governmental organizations (NGOs) to impart business ethics knowledge to Malaysian small and micro-businesses through active learning methods within a strategic implementation framework from 2017 to 2020 . The business ethics module project hence thrives to create consciousness on the importance of ethics and its application in Malaysian businesses. It therefore highlights one of the many initatives to enculturate and institutionalize ethics whilst Malaysia progresses as a highly middle-income economy, within a diverse global eco-system, promoting entrepreneurship and private sector participation for economic stability and social sustainability. Good and effective business decisions are an integration of economic, legal and moral viewpoints to uphold social justice. Malaysian businesses must be made aware of this important fact while they play a significant role in driving the nation's economic growth.

Ethics and consciousness are both phenomenal concepts. Ethics knowledge with practice, internalization and conviction are crucial as one plays specific roles in society, be it business or non-business. Character and values create impacts on society. The art of living is an art of character and making a good life requires crafting of one's soul in excellence (Gregory R. Beabout, 2018). As much as ethical practice is at most times personal, character building is also shaped by environmental factors that create ethical conscience and awareness. Collaborative efforts involving academics and industry practitioners to drive ethical conscience in Malaysia must continue as a commitment and social responsibility to support the nation's aspiration to be a developed nation by 2020, while upholding Rukun Negara principles and the Malaysian Constitution under nation building agendas.

\section{Acknowledgements}

The research and consulting team would like to express their heartiest gratitude to Ministry of Domestic Trade, Cooperatives and Consumerism Malaysia (KPDNKK) for providing a grant to realize the Malaysian Business Ethics Module (EPM) project. Appreciation also goes to all the public and private agencies as well as institutions that have effectively cooperated and contributed in their capacities while the team was gathering data for the development of the EPM module.

\section{References}

Abul Bashar Bhuiyan, Jamaliah Said, Md. Daud Ismail, Mohd Fauzi Mohd Jani and David Yong Gun Fie (2016). The innovation drivers, strategies and performance of food processing SMEs in Malaysia/. GEOGRAFIA OnlineTM Malaysian Journal of Society and Space 12 issue 2 (154 - 166) 154. Themed issue on contemporary financial, business, investment and entrepreneurial facets of Malaysia's development (C 2016, ISSN 2180-2491.

Ali Salman Saleh and Nelson Oly Ndubisi (2006). An Evaluation of SME Development in Malaysia. International Review of Business Research Papers Vol.2. No.1 August 2006, pp.1-14.

Azizul Azri Mustaffa (2016). Effective Implementation of Student Centred Learning, Part 1: Engaging Learners Through Active Learning. Universiti Teknologi Malaysia. Centre of Engineering Education (CEE), Johor Bharu, Johor Darul Takzim, Malaysia. 
Boatright, J.R. (2012). Ethics and the Conduct of Business (7th Ed). New Jersey: Pearson Education International.

Bonwell, C. C., and Eison, J.A. (1991). Active learning: creating excitement in the classroom. ASH\#- ERIC Higher Education Report No. 1, Washington, D.C.: The George Washington University, School of Education and Human Development.

Crane, A. and Matten, D. (2010). Business Ethics ( $3^{\text {rd }}$ Ed). New York: Oxford University Press.

Desjardins, J. (2009), An Introduction to Business Ethics ( $3^{\text {rd }}$ Ed.). McGraw Hill Higher Education, Singapore.

Ebert, R.J. And Griffin, R.W. ( 2007). Business Essentials (6th Ed.). New Jersey: Prentice Hall.

Eison, J. (2010). Using Active Learning Instructional Strategies to Create Excitement and Enhance Learning. Accessed https://www.cte.cornell.edu/documents/presentations/Eisen-Handout.pdf on 9 Feb, 2018 on 9 Feb, 2018.

Eleventh Malaysia Plan (2016-2020). Accessed from http://www.epu.gov.my/en/rmk/eleventh-malaysia-plan2016-2020 on 9 February 2018.

John F. Steiner and George A. Steiner (2012), Business Government and Society, 13 Edition, McGraw Hill Irwin International Edition, Singapore, pp.4.

Gregory R. Beabout (2018). Ethics The Art of Character.Worzalla Books Ltd. Glastonbury, UK.

Hafsah Hashim (2017). Adjunct lecture for Malaysian Economy (MPU3) Course. Anchoring SMEs for Growth by Datuk (Dr.) Hafsah Hashim, CEO SME Corp. Malaysia, Universiti Teknologi Petronas, 5 April, 2017.

Hafsah Hashim (2018). Announcement by CEO SMECorp Malaysia at The Malaysia Leadership Succession Summit 2018, 6-7 February, 2018, Sime Darby Convention Centre, Kuala Lumpur.

Hashim,H. (2015), SME Development Framework: The Malaysian Case, viewed 12 August 2015, <http://www.cbe.org.eg/.pdf>.

http://www.smecorp.gov.my/index.php/en/micro-enterprises accessed on 9 February, 2018.

Khairiah Mohd Yusof, Syed Ahmad Helmi Syed Hassan. Aziatul Niza Sadikin and Azizul Azri Mustaffa (2016).Effective Implementation of Student Centred Learning, Part 1: Engaging Learners Through Active Learning. Universiti Teknologi Malaysia. Centre of Engineering Education (CEE), Johor Bharu, Johor Darul Takzim, Malaysia.

Khalidah Khalid Ali (2017a). Enculturating Ethics through Active Learning: A study on Technical Students at a Private Malaysian University. Proceedings of ICERI2017 Conference,16th-18th November 2017, Seville, Spain ISBN: 978-84-697-6957-7, pp. 7338-46.

Khalidah Khalid Ali (2017b). Notes from lecture slides presented during MBA Energy Management Course for Ethics, Social Responsibility and Governance Module, Universiti Teknologi PETRONAS, 15-16 July, 2017

Khalidah Khalid Ali, Zulkufly Ramly and Lau Teck Chai (2014). Business Ethics. Oxford Fajar Sdn Bhd, Shah Alam, Selangor Darul Ehsan, Malaysia. pp. 201-206.

Khalidah Khalid Ali, Satirenjit Kaur, Lai Fong Woon, Rohani Salleh, Sofiah Molek Lope Aman Shah, Rahayu Abdul Rahman and Ilmiah Ibrahim ( 2015). Business Management: A Malaysian Perspective (3rd Ed). Syah Alam, Selangor darul Ehsan, Mlaysia: Oxford Fajar.

Khalidah Khalid Ali, Zulkufly Ramly and Lau Teck Chai (2018). Business Ethics. Second Edition, Oxford Fajar Sdn Bhd, Shah Alam, Selangor Darul Ehsan, Malaysia. 
Landauer, J. and Rowlands, J. (2001). The Five Branches of Philosophy. Importance of Philosophy. (n.d.). http://www.importance of philosophy.com. Accessed on 25 October 2013.

Laporan Akhir Projek Membangunkan Modul Etika Perniagaan Malaysia, 7 Februari, 2018.

Modul Etika Perniagaan Malaysia (Versi Rintis), 16 Disember, 2017.

Mohd Zulkifli Muhammad, Abdul Kamal Char, Mohd Rushdan Yasoa'and Zakiah Hassan (2010). Small and Medium Enterprises (SMEs) Competing in the Global Business Environment: A Case of Malaysia. International Business Research 3, no. 1 (2010): 66. [12].

Nickels, W.G., McHugh, J.M. and McHugh, S.M. (2008). Understanding Business (8th Ed.). New York: McGraw Hill/Irwin.

Nurulhasanah Abdul Rahman, Zulnaidi Yaacob and Rafisah Mat Radzi ( 2016). The Challenges Among Malaysian SME: A Theoretical Perspective. World Journal of Social Sciences Vol. 6. No. 3. September 2016. Pp. 124 - 132.

Shaw, W.H. ( 2011). Business Ethics ( 7th Edition), Belmont, CA: Thompson Wadsworth.

Siti Fatimah Hashim, Rosita Mohd.Tajuddin and Amer Shakir Zainol. (2015). Creating Resilient SME Through Brand Identity (Case Study of Bumiputera Fashion Entrepreneurs in Malaysia). International Academic Research Journal of Social Science 1(2)2015, pp.264-282.

Terma Rujukan Perunding Industri: Projek Merekayasa Pertumbuhan Ekonomi Untuk Peningkatan Kemakmuran.

Velasquez, M.G. (2012). Business Ethics: Concepts and Cases ( $7^{\text {th }}$ Ed.). United States of America: Pearson Education. 